\title{
Short-term variability in the assemblage of medusae and ctenophores following upwelling events in the southern Benguela ecosystem
}

\author{
Mark J. Gibbons ${ }^{1}$, Emmanuelle Buecher ${ }^{1,2}$ \\ ${ }^{1}$ Zoology Department, University of the Western Cape, Private Bag X17, Bellville 7535, South Africa \\ ${ }^{2}$ Laboratoire d'Océanographie Biologique et Ecologie du Plancton Marin, CNRS/UPMC 7076 Station Zoologique, \\ B.P. 28, 06234 Villefranche-sur-mer, France
}

\begin{abstract}
Changes in the composition of the assemblage of medusae and ctenophores were examined daily over a period of $28 \mathrm{~d}$, encompassing 3 upwelling events in a non-advective environment within the southern Benguela ecosystem. The relationships between assemblage composition and the environment were analysed using canonical correspondence analyses. Although distinct assemblages were associated with upwelling itself, as well as with the periods of water column stabilisation and stratification, indicator species for the assemblages could not be identified. This reflected the near ubiquitous nature of most assemblage members, and their probable response to historical (unmeasured) environmental variables. That notwithstanding, it is clear that short-term changes in characteristics of the surface and deeper water environment are reflected by short-term changes in the composition of the gelatinous zooplankton assemblage. This is more reminiscent of phytoplankton than holozooplankton and probably reflects the meroplanktic nature of most assemblage members.
\end{abstract}

KEY WORDS: Cnidaria · Jellyfish · Zooplankton · Communities · South Africa $\cdot$ Canonical correspondence analysis

\section{INTRODUCTION}

Changes in the physical environment that accompany and follow upwelling tend to be reflected in phytoplankton assemblages. At the onset of upwelling, assemblages are dominated by diatoms, which are then replaced by dinoflagellates and microflagellates, as the water column stabilises (Margalef 1962, Pitcher et al. 1991). Specific changes in assemblage composition are accompanied by an initial peak in biomass and production, followed by gradual declines in both as the thermocline deepens and new nitrogen is stripped from the euphotic zone (Mitchell-Innes \& Walker 1991).

This autochthonous process of succession is not usually reflected in the zooplankton (e.g. Verheye 1991). Hutchings (1992) suggested that the discrepancy in the

*E-mail: mgibbons@uwc.ac.za timing of the biomass peaks of zooplankton and phytoplankton in upwelling areas may be due to differences in their respective response times to the environment. In the southern Benguela ecosystem, the generation time of mesozooplankton is approximately $20 \mathrm{~d}$, while phytoplankton blooms may develop and then crash within $10 \mathrm{~d}$.

However, in most upwelling areas the temporal changes that would be observed in phytoplankton assemblages during succession appear as spatial, cross-shelf, changes in zooplankton. For an individual holozooplankter, therefore, the difference in response time may be overcome by behavioural adaptations (Peterson et al. 1988) that maximise spatial overlap. Such has been demonstrated for the dominant species of 'herbivorous' copepod (Verheye et al. 1991), and for the most common species of omnivorous euphausiid (Pillar et al. 1992) in the southern Benguela ecosystem. It is also reflected in the more general size structure of 
the overall zooplankton assemblage across the shelf (Hopson 1983, Gibbons \& Hutchings 1996). On a larger scale, it can also be argued that succession is reflected in cross-shelf changes in the trophic structure of assemblages (Steele 1974).

The lack of a clear pattern in the zooplankton assemblage in response to short-term variability in the physical environment may be due to our tendency to focus on holoplanktic species. This paper sets out to investigate whether a similar lack of concordance is observed amongst those components of zooplankton assemblages that are substantially meroplanktic. Here, we examine changes in the composition of the assemblage of medusae and ctenophores in St Helena Bay, following an upwelling event. It builds on a suite of papers describing the biophysical environment and processes during a $28 \mathrm{~d}$ anchor station study (Chapman \& Bailey 1991), during which it was observed that there were few links between the patterns of phyto- and holozooplankton (Verheye 1991).

\section{MATERIALS AND METHODS}

Field sampling. The fixed sampling site was at $32^{\circ}$ $33.2^{\prime} \mathrm{S}, 18^{\circ} 05.3^{\prime} \mathrm{E}$ in St Helena Bay (South Africa), where the RS 'Benguela' was anchored for $28 \mathrm{~d}$ from 19 March to 15 April 1987. St Helena Bay is a semisheltered embayment downstream of the Cape Columbine upwelling centre. Water circulation in the bay is relatively sluggish and is dominated at the surface by a cyclonic gyre (Shannon 1985), which allows large populations of phytoplankton to develop.

Zooplankton samples were collected daily at $12: 00 \mathrm{~h}$ (diurnal) and 20:00 h (nocturnal) (SAST) from 20 March until 15 April using paired Bongo nets. As large medusae were scarce in St Helena Bay at the time of sampling, we used nets with a mouth diameter of $0.57 \mathrm{~m}(200 \mu \mathrm{m}$ mesh size). The nets were hauled vertically at $1 \mathrm{~m} \mathrm{~s}^{-1}$ from $2 \mathrm{~m}$ above the bottom $(47 \mathrm{~m})$ to the surface. The volume of water filtered by the nets was calculated from an electronic flowmeter mounted centrally in the mouth of one net. No samples were collected at noon on 27 March and 6 April, and those from 28 and 29 March are missing. All samples were fixed in $5 \%$ buffered saline formalin.

Information on the physical (surface and bottom temperature, and salinity), and chemical (surface and bottom concentrations of silicate, nitrate, nitrite and dissolved oxygen) characteristics of the water column was collected concurrently with the samples of gelatinous zooplankton, using a Neil-Brown Mk 3b CTD and rosette sampler (Bailey \& Chapman 1991). The concentration of chlorophyll a from above the thermocline at each station was determined from samples of $1 \mathrm{dm}^{3}$ volume that were filtered through Whatman GF/F filters and analysed using a modification of the SCORUNESCO method (Strickland \& Parson 1972).

All medusae and ctenophores from all samples were identified and counted, where possible. Owing to problems in the consistent separation of Clytia simplex and Clytia hemisphaerica, these species have been combined. Less than $0.2 \%$ (corresponding to a total of 14 individuals) of the material could not be identified owing to poor preservation or mechanical damage. The data from each night sample were combined with those from the following day. This simplifies the data set and links observations to the lunar cycle. It also permits a daily comparison with the other data sets (e.g. Verheye 1991). Species diversity (Shannon Index) was calculated for each sample.

Statistical analysis and data handling. The relationships between the measured environmental variables and the assemblages were investigated using Canonical Correspondence Analysis (CCA; ter Braak \& Prentice 1988). This statistical method is beginning to enjoy more widespread use by marine ecologists (ter Braak \& Verdonschot 1995, Oug 1998), as it has several advantages over other types of gradient analyses (Attayde \& Bozelli 1998). The technique essentially maximises the dispersion of species (and samples) along axes representing linear combinations of the environmental variables, and the results can be displayed as ordination plots. Sample and species are marked on the ordination plot as points that represent their mean species compositions and distribution optima respectively. The environmental variables are seen as vectors that point towards the maximum increase of the variable. Long vectors represent strong trends, and the angle between pairs of vectors approximates the correlation between the respective variables (the more acute the angle, the greater the correlation). The importance of the axes is indicated by the eigenvalue (extracted variance), which may be compared to total variance in the species data to indicate the proportion of the species variation that is attributable to the environmental data.

The analyses were performed only on those species that occurred in more than $10 \%$ of the samples, following square-root transformation. These dominant species are considered to be the most informative members of the assemblage (Marchant 1999), and by ignoring rare species we avoid some of the implications imposed by the small net size. The environmental variables were de-spiked using a $3 \mathrm{~d}$ running-mean, and those selected for final inclusion in the analysis included those that were maximally related to species distribution (as identified by 'forward selection' procedures and Monte Carlo permutation tests). The analyses were performed using CONOCO 4 software (ter Braak \& Smilauer 1998). 


\section{RESULTS}

\section{Environment}

Full details on the environment at the time of sampling can be found in Bailey \& Chapman (1991), Mitchell-Innes \& Walker (1991), Pitcher et al. (1991) and Verheye (1991), from which the following has been culled. Water that was upwelled at Cape Columbine was advected into the study area some 2 to $3 \mathrm{~d}$ later on 3 occasions, namely March 19/20, April 10/11 and April 14/15 (Bailey \& Chapman 1991). The first of these events was followed by an extended period of relaxation during which significant stratification developed (5 to 10 April; Fig. 1a), whereas the second event was followed only by a very brief quiescent period prior to interruption by the third event. Otherwise, there was no net movement of water into the bay (Bailey \& Chapman 1991). Two phytoplankton blooms were observed, both of which were directly related to the intrusion of upwelled water (Fig. 1b). Four temporally distinct phytoplankton assemblages were observed (Fig. 3b, Pitcher et al. 1991), which correspond to the periods March 20 to 26/27, March 26/27 to April 4/5, April 4/5 to 10/12 and April 10/12 to 15 . The communities observed during these periods were dominated by large diatoms, dinoflagellates, microflagellates, and small diatoms respectively, and they were consistent with the periods of initial upwelling, developing stratification, developed stratification and renewed upwelling.

\section{Gelatinous zooplankton}

A total of 22 species of medusae, and 2 species of ctenophores were collected during the $28 \mathrm{~d}$ study period (Table 1). Although the medusae included represen-

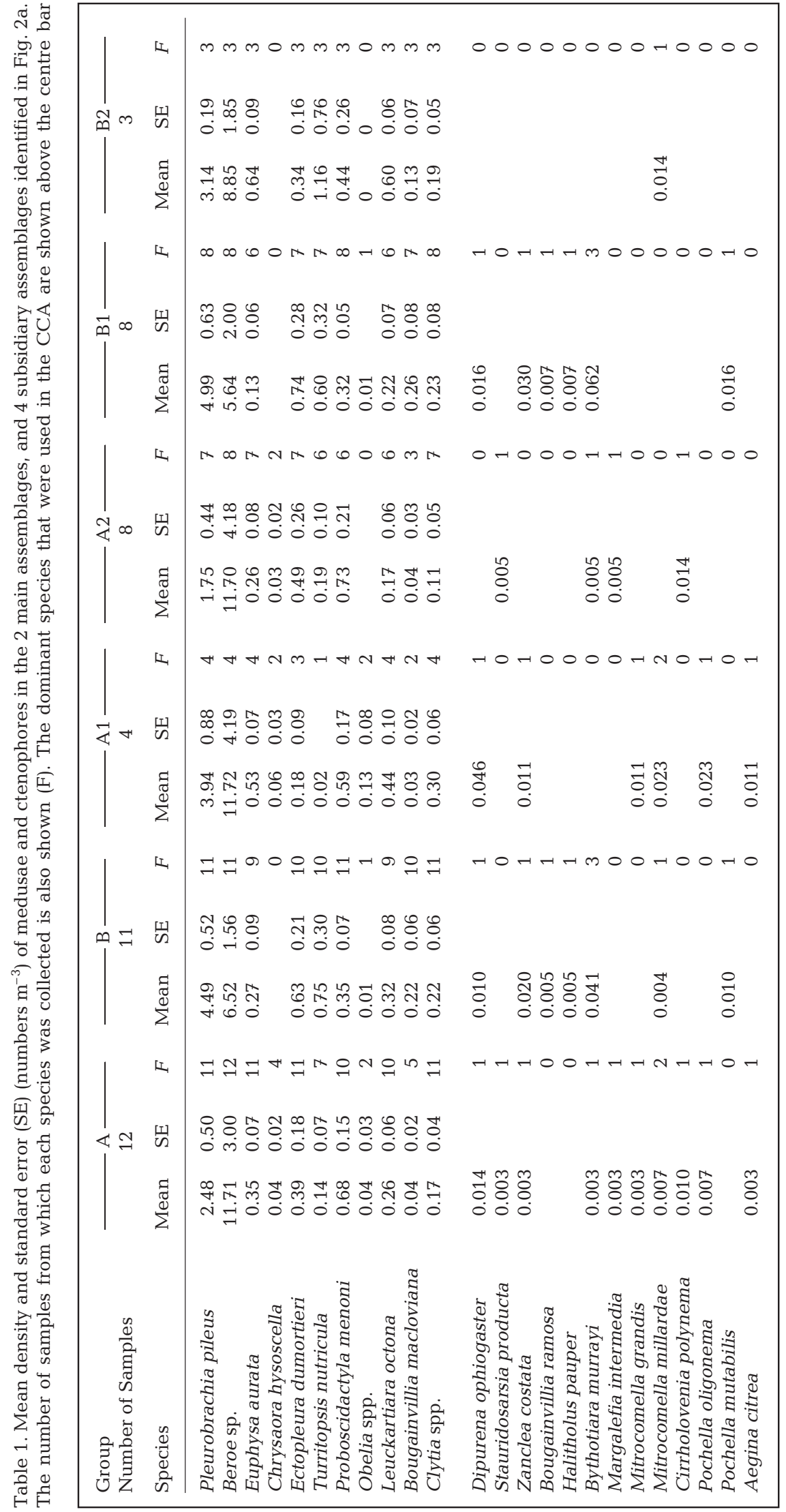




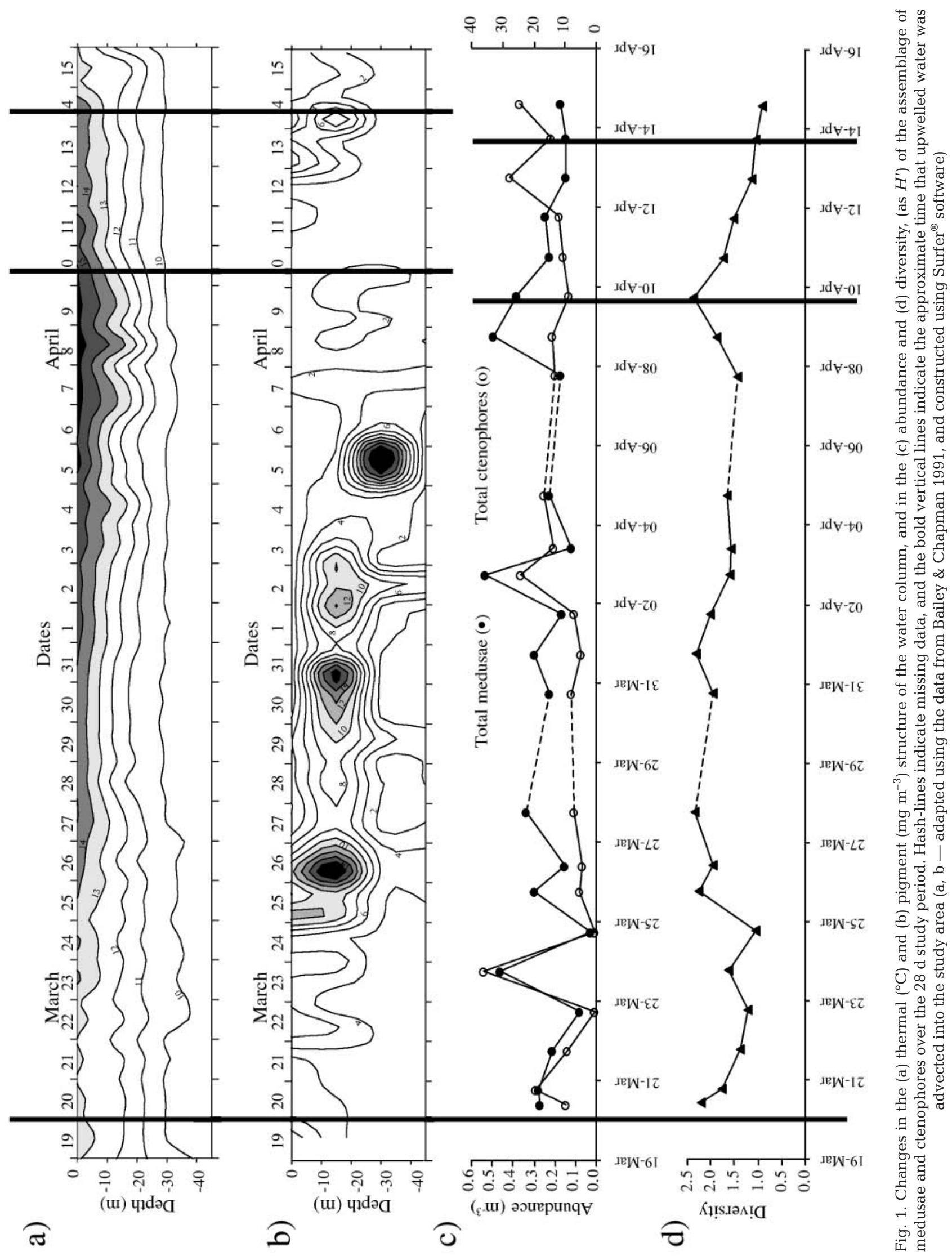


tatives from all the hydrozoan subclasses and 1 scyphozoan, many of the species were recorded in less than 3 samples. Indeed, the medusan assemblage was dominated by only 9 species, which occurred in more than $50 \%$ of the samples (Table 1). If the diversity of the samples was largely accounted for by the medusae, the ctenophores (especially Beroe sp.) dominated numerically (max: 65.41 ind. $\mathrm{m}^{-3}$ ).

The abundance of medusae and ctenophores fluctuated in a similar manner throughout the study period (Fig. 1c), although there did not appear to be any relationship between abundance and upwelling. The diversity of the assemblage declined slightly after each of the first 2 upwelling events (Fig. 1d), but remained more or less constant during the long period of stabilisation following the first upwelling event.

\section{Assemblages}

The first 2 CCA axes of the ordination had eigenvalues of 0.056 and 0.031 (Table 2), respectively, which accounted for $58.6 \%$ of the total variance in the weighted averages of the species. The species-environment correlation coefficients for the first $2 \mathrm{CCA}$ axes were 0.97 and 0.95 , respectively, which suggests a strong relationship between the species and the environment in both axes.

The environmental variables of surface nitrate, temperature and nitrite, as well as silicate, oxygen and chlorophyll accounted for the highest fractions of the species variation, as indicated by the inertia values in Table 3a. Through the forward selection procedure, the variables of surface nitrate and temperature, and bottom silicate, oxygen, nitrate, salinity and nitrite were found to constitute the best combination. In other words, a greater amount of the variance was accounted for by these variables in combination than by any single variable on its own (hence added inertia; see Table 3a). Surface nitrite, chlorophyll, oxygen and silicate were not selected, indicating that they did not contribute any significantly unique
Table 2. CCA results I. Eigenvalues of the 4 axes of the CCA for the dominant medusae and ctenophores over the $28 \mathrm{~d}$ study period. Also shown are the species-environment correlations (which measure the strength of the relationship between species and environment for a particular axis), as well as the percentage variance of the species data explained by the axes, and by the environmental variables

\begin{tabular}{|ccccc|}
\hline Axes & Eigenvalue & $\begin{array}{c}\text { Species- } \\
\text { environment } \\
\text { correlation }\end{array}$ & $\begin{array}{c}\text { Cumulative variance (\%) } \\
\text { Species } \\
\text { data }\end{array}$ & $\begin{array}{c}\text { Species-environment } \\
\text { relation }\end{array}$ \\
\hline 1 & 0.056 & 0.972 & 37.7 & 46.9 \\
2 & 0.031 & 0.946 & 58.6 & 72.8 \\
3 & 0.024 & 0.951 & 74.8 & 92.9 \\
4 & 0.006 & 0.801 & 78.7 & 97.8 \\
Total & 0.352 & & & \\
\hline
\end{tabular}

information. Some of the variables (e.g. bottom temperature) were poorly related to species distribution.

The correlation coefficients between these ordination axes and the environmental variables (Table $3 \mathrm{~b}$ ) showed that the first axis was most strongly linked to attributes of the surface water, whereas the second axis had higher correlations with bottom water variables. Both axes were highly significant $(p=0.005)$ in the Monte Carlo test with 199 permutations.

The separation of samples along the $x$-axis of the ordination diagram (Fig. 2a) clearly illustrates the influence of developing stratification (as indicated by $\mathrm{SST}$ and $\mathrm{SSNO}_{3}$ ). Assemblages collected during, or soon after, upwelling can be seen to the right in Fig. 2a. The separation of samples on the $y$-axis is not as readily interpretable, but changes in the concentration of
Table 3. CCA results II. The extracted variance in the species data set attributable to each individual environmental variable (inertia), and the added variance accounted for by variables selected one by one in sequence (added inertia). The variables found significant $(p<0.05)$ in Monte Carlo permutation tests indicated (a). Weighted correlation coefficients between the environmental variables and the first 2 axes of the CCA ordination (b)

\begin{tabular}{|c|c|c|c|c|}
\hline \multirow[b]{2}{*}{ Environmental variable } & \multicolumn{2}{|c|}{$\begin{array}{c}\mathrm{a} \\
\text { Forward selection }\end{array}$} & \multicolumn{2}{|c|}{ b } \\
\hline & Inertia & Extra inertia & $x$-axis & $y$-axis \\
\hline Sea surface nitrate $\left(\mathrm{SSNO}_{3}\right)$ & 0.05 & 0.05 & 0.905 & 0.180 \\
\hline Sea surface temperature (SST) & 0.05 & 0.02 & -0.857 & -0.102 \\
\hline Sea surface nitrite $\left(\mathrm{SSNO}_{2}\right)$ & 0.05 & - & - & - \\
\hline Sea surface silicate (SSSi) & 0.04 & - & - & - \\
\hline Sea surface dissolved oxygen $\left(\mathrm{SSO}_{2}\right)$ & 0.04 & - & - & - \\
\hline Sea surface chlorophyll (SSChl) & 0.04 & - & - & - \\
\hline Sea surface salinity (SSS) & 0.03 & - & - & - \\
\hline Bottom silicate (BSi) & 0.03 & 0.03 & -0.35 & -0.531 \\
\hline Bottom nitrite $\left(\mathrm{BNO}_{2}\right)$ & 0.02 & - & - & - \\
\hline Bottom temperature (BT) & 0.02 & - & - & - \\
\hline Bottom salinity (BS) & 0.02 & 0.01 & 0.244 & 0.451 \\
\hline Bottom nitrate $\left(\mathrm{BNO}_{3}\right)$ & 0.01 & 0.01 & 0.096 & 0.440 \\
\hline Bottom dissolved oxygen $\left(\mathrm{BO}_{2}\right)$ & 0.01 & 0.01 & 0.324 & 0.163 \\
\hline
\end{tabular}


dissolved nitrite, nitrate and silicate in the bottom water appear to be linked to the separation of samples collected subsequent to the first and second upwelling events. Two groups of samples have been encircled that are spatially separated among the 2 CCA axes. These generally correspond to assemblages collected during, and soon after, the 3 upwelling events (group A), and assemblages collected during the period of stratification following the first upwelling event (group B). The assemblages from group A can be further separated into those collected during, and immediately after, the first and third upwelling events (group A1), and those collected during the period of maturation following the first upwelling event, and during the second upwelling event (group A2). There is no clear distinction between assemblages within group B, although those collected immediately prior to the second upwelling event (when the water column was most stratified), do tend to group together (group B2).

Most of the species were found at the centre of the ordination diagram (Fig. 2b), which reflects their widespread occurrence in the samples. As a consequence, they showed no clear relationship with environmental variables. The medusae of Obelia, and the ephyrae of Chyrsaora hysoscella, by contrast, were quite clearly separated from the remainder of the species and appeared to be found when the surface temperature was low and surface nitrate concentrations were high.

\section{DISCUSSION}

The medusae and ctenophores collected during the present study are all neritic species (Bouillon 1999, Mianzan 1999) that have been reported previously from the region (Pagès et al. 1992, Buecher \& Gibbons 2000). The richness of the assemblage was largely accounted for by the meroplanktic species (medusae), but it was the holoplanktic species (in this case, ctenophores) that dominated numerically. This pattern seems to be the norm for coastal and shelf ecosystems, including the southern Benguela (Buecher \& Gibbons in press).

Upwelling is generally followed by a series of clearly recognisable changes in the physical and chemical environment, which are reflected in (and partly brought about by), successional changes in the composition and processes of the phytoplankton community (Margalef 1962, Mitchell-Innes \& Walker 1991). The response by the assemblage of medusae and ctenophores to the changing physical environment that was observed during the upwelling cycle was broadly similar to that of the phytoplankton com-
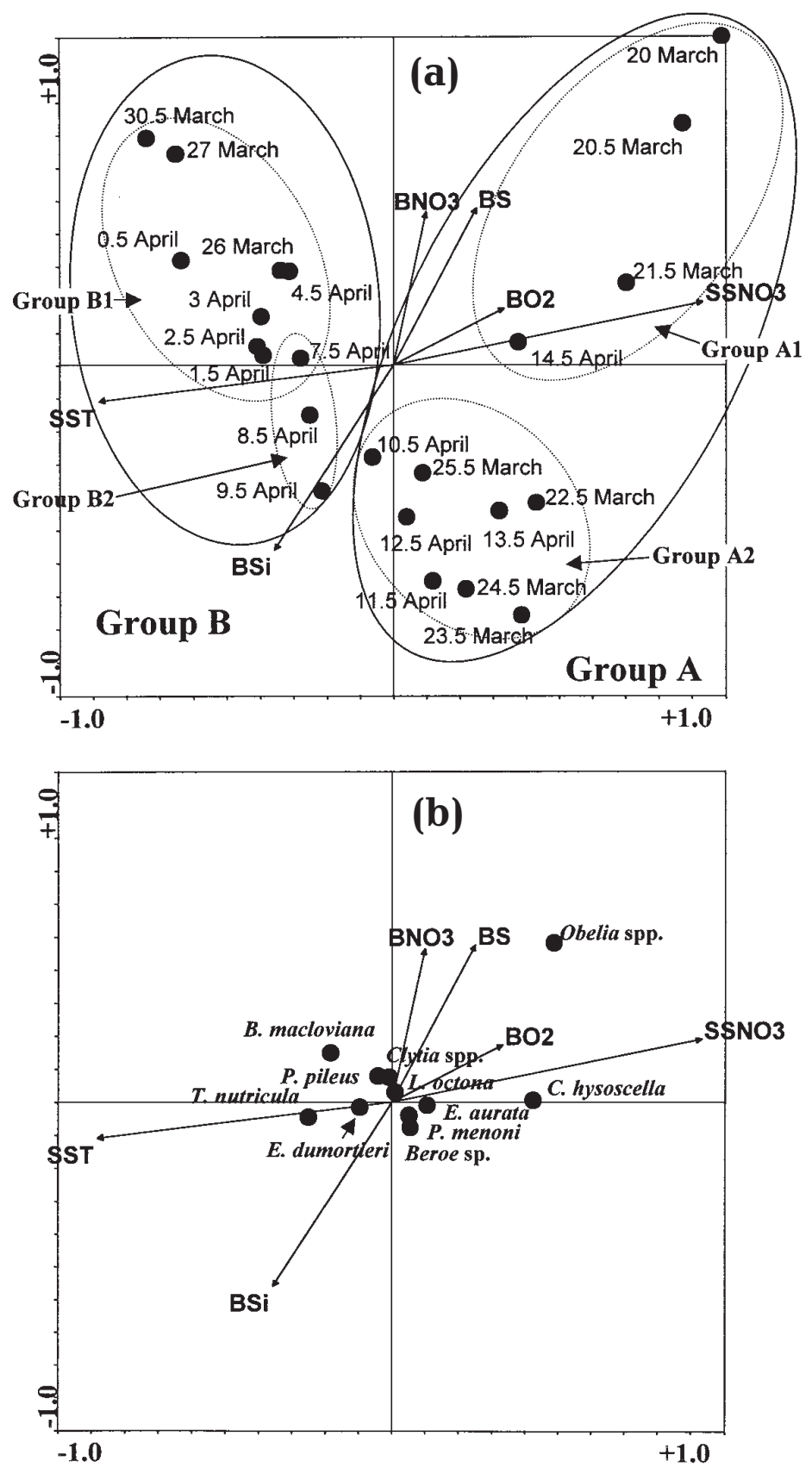

Fig. 2. Ordination diagrams based on canonical correspondence analysis of the (a) assemblage and (b) species of medusae and ctenophores in St Helena Bay, over the $28 \mathrm{~d}$ study period, with respect to the environmental variables selected by the 'forward selection' procedure (Table 3). Arrows show the magnitude (length) and direction of the environmental vectors (key to variable names in Table 3). The assemblage groupings identified in (a), correspond to samples collected during periods of upwelling (group A) and stratification (group B)

munity, and distinct assemblages were associated with recently upwelled, and stratified water (Fig. 2a). There is a suggestion from Fig. 2a that the pattern 
may be repeatable, as evidenced by the close grouping of samples collected during the different upwelling events (group A). However, the eigenvalues associated with the axes were low. This comes as little surprise owing to the meroplanktic nature of most assemblage members and their dependence on the historical (unmeasured) environment. While this does constrain detailed interpretation, there is likely to be some historical signal contained within the measured variables.

Unlike the phytoplankton communities (Pitcher et al. 1991), those of the medusae and ctenophores could not be characterized by indicator species. The reason for this is that most of the species found in the assemblages were present most of the time and it was only their relative abundances that varied. This result contrasts with that of other CCAs (e.g. Bustamante et al. 1997, Oug 1998), which have tended to focus on spatial changes in assemblages across strong environmental gradients, where there are clear species-specific responses to the environment.

The absence of indicator species for each assemblage also contrasts with the results of studies exploring (spatially inferred) mesoscale coupling between upwelling and pelagic cnidarians in the region (Pagès \& Gili 1991, Pagès et al. 1991, Pagès 1992). These authors noted that inshore assemblages indicative of upwelled water were dominated by meroplanktic hydromedusae of the same species found here, but that warmer, offshore waters were characterised by holoplanktic medusae and siphonophores. The lack of agreement between the results of the studies by Pagès et al. (1991) and Pagès (1992), and those presented here lies in their relative scales and in the relative significance of advection, and is to be expected. Indeed, the results of Pagès et al. (1991) and Pagès (1992) reflect the more general, cross-shelf characteristics of the environment (Gibbons \& Hutchings 1996), rather than changes taking place in the upwelled water itself.

The lack of obvious species-specific responses to the environment, and the shared nature of most assemblage members observed here, makes it difficult to interpret the changes in assemblage composition as a product of the rapid, differential appearance and disappearance of individual species. Rather, the changes are effected through more subtle and ongoing alterations in the environment that favour the gradual recruitment and differential survival of assemblage members. Given that the structure of the assemblages was linked to characteristics of both the surface and the bottom water, it is clear that autochthonous (birth and death within a water layer), and allochthonous (advection and migration between water layers) process were taking place.

\section{Autochthonous processes}

Despite the fact that most of the species are probably eurythermal (over the temperature range observed here), the process of birth can be triggered by a variety of species-specific environmental cues including temperature, food availability, lunar cycles and salinity (e.g. Werner 1958, Goy 1973, Arai 1992). Few of the species attain large size, and they are therefore likely to have high metabolic rates (Bailey et al. 1994), and naturally short residence times (Mills 1993) that may have evolved to suit the local environment (Boero et al. 1997). Mortality appears to be primarily effected through predation (but see Mills 1993), which in the case of small species is likely to be selectively caused by other members of the assemblage (e.g. Purcell 1991a,b), rather than by vertebrates (Arai 1988, Ates 1988, Den Hartog 1980, Harrison 1984).

\section{Allochthonous processes}

Current measurements indicate that the water within the bay was trapped in a cyclonic gyre (G. Nelson pers. comm.), and that there was no net advection into the bay during the course of the study period (except for that associated with the upwelling events themselves, Bailey \& Chapman 1991). As a consequence, the physico-chemical environment at the anchor station can be seen as representative of the wider bay environment. This was evidenced by the fact that the phytoplankton communities did not display significant heterogeneity in composition that could be linked to patchiness (Pitcher et al. 1991). It should be noted, however, that the surface and deepwater layers typically moved at $90^{\circ}$ to each other (Bailey \& Chapman 1991). This means that some variation in assemblage composition could be linked to the patchy distribution of polyps and medusae within the bay, and to the differential patterns of migration between layers by assemblage members. Our understanding of the vertical distribution of medusae in the Benguela ecosystem is poor, but there is evidence to suggest that 3 of the common species (Bougainvillia macloviana, Obelia spp. and Clytia spp.) are epipelagic. These species display limited vertical migration within the upper water layers, and do not cross the thermocline (Gibbons et al. 1999). The 2 species of ctenophores are also thought to be largely epipelagic, but the evidence to suggest that they display vertical migration is contradictory (Fraser 1970, Hirota 1974, Frank 1986, Wang et al. 1995).

A lack of understanding regarding the precise mechanism of change obviously complicates a clear interpretation of the results, but it is likely that both alloc- 
thanous and autochthonous processes were taking place. That notwithstanding, the results demonstrate that small-scale changes in the environment following upwelling were accompanied by small-scale changes in the assemblage of medusae and ctenophores. While it is perhaps counter-intuitive to observe responses to upwelling by carnivorous, rather than herbivorous, taxa this probably reflects the meroplanktic life-cycle of the former rather than trophic mode per se. Such species (as a group) are able to make observable, rapid responses to short-term changes in the physical environment, and their benthic stages are placed in an environment (inshore) that allows immediate recruitment to the plankton of upwelled water. Although newly released medusae and ephyrae are unlikely to be supplied with extensive food reserves, they are small and are known to feed on microzooplankton (Stoecker et al. 1987) that respond more rapidly to the changing environment than larger mesozooplankton do. It is suggested that the reduction in response time (given too that medusae are the biggest predators of other medusae, Purcell 1991a,b), coupled with the environmental sensitivity and the near-shore distribution of polyp stages, allow us to detect short-term changes in assemblage composition that have not hitherto been observed for holoplanktic crustaceans.

Acknowledgements. We would like to thank Marine and Coastal Management (M\&CM) for giving us permission to explore archived zooplankton samples, and for giving us access to environmental data. Thanks are due to Drs Delphine Thibault, Hans Verheye and Larry Hutchings for their constructive comments on earlier versions of the manuscript, as well as to the anonymous referees. We are grateful to M\&CM for logistic support, and to Drs Grev. Nelson and Geoff Bailey for discussing the physical oceanography with us. Funding to support this project came from the France-South Africa Science and Technology Exchange Agreement, and from the National Research Foundation. Financial support for E.B. was also provided by the Singer Polignac Foundation.

\section{LITERATURE CITED}

Arai MN (1988) Interactions on fish and pelagic coelenterates. Can J Zool 66:1913-1927

Arai MN (1992) Active and passive factors affecting aggregations of hydromedusae: a review. Sci Mar 56:99-108

Ates RML (1988) Medusivorous fishes, a review. Zool Mededelingen 62:29-42

Attayde JL, Bozelli RL (1998) Assessing the indicator properties of zooplankton assemblages to disturbance gradients by canonical correspondence analysis. Can J Fish Aquat Sci 55:1789-1797

Bailey GW, Chapman P (1991) Short-term variability during an anchor station study in the southern Benguela upwelling system: chemical and physical oceanography. Prog Oceanogr 28:9-37

Bailey TG, Torres JJ, Youngbluth MJ, Owen GP (1994) Effect of decompression on mesopelagic gelatinous zooplankton: a comparison of in situ and shipboard measurements of metabolism. Mar Ecol Prog Ser 113:13-27

Boero F, Buoillon J, Piraino S, Schmid V (1997) Diversity of hydroidomedusan life cycles: ecological implications and evolutionary patterns. In: Proceedings of the $6^{\text {th }}$ International Conference on Coelenterate Biology, p 53-62

Bouillon J (1999) Hydromedusae. In: Boltovskoy D (ed) South Atlantic zooplankton. Backhuys, Leiden, p 385-465

Buecher E, Gibbons MJ (2000) Interannual variation in the composition of the assemblages of medusae and ctenophores in St Helena Bay, southern Benguela ecosystem. Sci Mar 64(Suppl):123-134

Bustamente RH, Branch GM, Eekhout S (1997) The influences of physical factors on the distribution and zonation patterns of South African rocky shore communities. S Afr J Mar Sci 18:119-136

Chapman P, Bailey GW (1991) Short-term variability during an anchor station study in the southern Benguela upwelling system: Introduction. Prog Oceanog 28:1-7

Den Hartog JC (1980) Notes on the food of sea turtles: Eretmochelys imbricata (Linnaeus) and Dermochelys coriaca (Linnaeus). Neth J Zoology 30:595-610

Frank KT (1986) Ecological significance of the ctenophore Pleurobrachia pileus off Southwestern Nova Scotia. Can J Fish Aquat Sci 43:211-222

Fraser JH (1970) The ecology of the Ctenophore Pleurobrachia pileus in Scottish waters. J Cons Perm Int Explor Mer 33:149-168

Gibbons MJ, Hutchings L (1996) Zooplankton diversity and community structure around southern Africa, with special attention to the Benguela upwelling system. S Afr J Sci 92: $63-76$

Gibbons MJ, Gugushe N, Boyd AJ, Shannon LJ, MitchellInnes BA (1999) Changes in the composition of the noncopepod zooplankton assemblage in St Helena Bay (southern Benguela ecosystem) during a six-day drogue study. Mar Ecol Prog Ser 180:111-120

Goy J (1973) Gonionemus suavensis: structural characters, developmental stages and ecology. Publs Seto Mar Biol Lab 20:525-536

Harrison NM (1984) Predation on jellyfish and their associates by seabirds. Limnol Oceanogr 29:1335-1337

Hirota J (1974) Quantitative natural history of Pleurobrachia bachei in La Jolla Bight. Fish Bull 72:295-335

Hopson SD (1983) Pelagic copepods of Lambert's Bay. An ecological study of a West Coast fishing ground. MSc thesis, University of Cape Town

Hutchings L (1992) Fish harvesting in a variable, productive environment-searching for rules or searching for exceptions? S Afr J Mar Sci 12:297-318

Marchand R (1999) How important are rare species in aquatic community ecology and bioassessment? A comment on the conclusions of Cao et al. Limnol Oceanogr 44:1840-1841

Margalef R (1962) Succession in marine populations. Adv Front Plant Sci 2:137-188

Mianzan HW (1999) Ctenophora. In: Boltovskoy D (ed) South Atlantic zooplankton. Backhuys, Leiden, p 561-573

Mills CE (1993) Natural mortality in NE Pacific coastal hydromedusae: grazing predation, wound healing and senescence. Bull Mar Sci 53:194-203

Mitchell-Innes BA, Walter DR (1991) Phytoplankton production and biomass relation to species changes. Prog Oceanogr 28:65-90

Oug E (1998) Relating species patterns and environmental variables by canonical ordination: an analysis of softbottom macrofauna in the region of Tromsø, Northern Norway. Mar Environ Res 45:29-45 
Pagès F (1992) Mesoscale coupling between planktonic cnidarian distribution and water masses during a temporal transition between active upwelling and abatement in the northern Benguela system. S Afr J Mar Sci 12:41-52

Pagès F, Gili JM (1991) Effects of large-scale advective processes on gelatinous zooplankton populations in the northern Benguela ecosystem. Mar Ecol Prog Ser 75: 205-215

Pagès F, Verheye HM, Gili JM, Flos J (1991) Short-term effects of coastal upwelling and wind reversals on assemblages of epiplanktonic cnidarians in the southern Benguela region. S Afr J Mar Sci 10:203-212.

Pagès F, Gili JM, Bouillon J (1992) Medusae (Hydrozoa, Scyphozoa, Cubozoa) of the Benguela Current (South eastern Atlantic). Sci Mar 56:1-64

Peterson WT, Arcos DF, McManus GB, Dam H, Ballantoni D, Johnson T, Tiselius $P$ (1988) The nearshore zone during coastal upwelling: daily variability and coupling between primary and secondary production off central Chile. Prog Oceanogr 20:1-40

Pillar SC, Stuart V, Barange M, Gibbons MJ (1992) Community structure and trophic ecology of euphausiids in the Benguela ecosystem. In: Payne AIL, Brink KH, Mann KH, Hilborn R (eds) Benguela trophic functioning. S Afr J Mar Sci 12:393-409

Pitcher GC, Walker DR, Mitchell-Innes, Moloney CL (1991) Phytoplankton dynamics. Prog Oceanog 28:39-64

Purcell JE (1991a) A review of cnidarians and ctenophores feeding on competitors in the plankton. Hydrobiologia 216/217:335-342

Purcell JE (1991b) Predation by Aequorea victoria on other species of potentially competing pelagic hydrozoans. Mar Ecol Prog Ser 72:255-260

Shannon LV (1985) The Benguela ecosystem. 1. Evolution of

Editorial responsibility: Jennifer Purcell,

Cambridge, Maryland, USA the Benguela, physical features and processes. Oceanogr Mar Biol Annu Rev 23:105-182

Steele JH (1974) The structure of marine ecosystems. Blackwell, Oxford

Stoecker DK, Michaels AE, Davis LH (1987) Grazing by the jellyfish, Aurelia aurita, on microzooplankton. J Plankton Res 9:901-915

Strickland JDH, Parsons TR (1972) A practical handbook of seawater analysis. Fish Res Board Canada Bull 167, p 310

ter Braak CJF, Prentice, IC (1988) A theory of gradient analysis. Adv Ecol Res 18:271-317

ter Braak CJF, Smilauer P (1998) CANOCO reference manual and user's guide to Canoco for Windows: software for canonical community ordination (v4). Microcomputer Power, Ithaca, NY

ter Braak CJF, Verdonschot PFM (1995) Canonical correlation analysis and related multivariate methods in aquatic ecology. Aquat Sci 57:255-289

Verheye HM (1991) Abundance, distribution and estimated production of mesozooplankton with special reference to Calanoides carinatus (Kroyer, 1849). Prog Oceanogr 28: 91-120

Verheye HM, Hutchings L, Peterson WT (1991) Life history and population maintenance strategies of Calanoides carinatus (Copepoda: Calanoida) in the southern Benguela ecosystem. S Afr J Mar Sci 11:179-191

Wang Z, Thiébaut E, Dauvin J-C (1995) Spring abundance and distribution of the ctenophore Pleurobrachia pileus in the Seine estuary: advective transport and diel vertical migration. Mar Biol 124:313-324

Werner B (1958) Die Verbreitung und das jahreszeitliche Auftreten der Anthomeduse Rathkea octopunctata M. Sars, sowie die Temperaturabhängigkeit ihrer Entwicklung und Fortpflanzung. Helgol Wiss Meeresunters 6:137-170

Submitted: February 28, 2000; Accepted: February 1, 2001 Proofs received from author(s): August 29, 2001 